Article

\title{
Methanol-to-olefin induction reaction over SAPO-34
}

\author{
You Zhou a,b, Liang Qi a,b, Yingxu Wei a, Cuiyu Yuan a, Mozhi Zhang a,b, Zhongmin Liu a,* \\ a Dalian National Laboratory for Clean Energy, National Engineering Laboratory for Methanol to Olefins, Dalian Institute of Chemical Physics, Chinese \\ Academy of Sciences, Dalian 116023, Liaoning, China \\ b University of Chinese Academy of Sciences, Beijing 100049, China
}

\section{A R T I C L E I N F O}

\section{Article history:}

Received 26 March 2016

Accepted 18 April 2016

Published 5 September 2016

\section{Keywords:}

Methanol-to-olefin

Activation energy

SAPO-34

Hydrocarbon pool

Induction period

\begin{abstract}
A B S T R A C T
The methanol-to-olefin induction reaction over the SAPO-34 was performed using a fluidized-bed system. We found that the whole induction period could be divided into three reaction stages. Further investigation of the reaction kinetics revealed that this induction reaction behavior was different from that over H-ZSM-5 catalyst. Compared with the H-ZSM-5, the generation of initial active centers is easier over SAPO-34 because of its limited diffusivity and the spatial confinement effect of the cages. However, the autocatalysis reaction stage is difficult over SAPO-34 because of the continuous formation of inactive methyladamantanes.
\end{abstract}

(C) 2016, Dalian Institute of Chemical Physics, Chinese Academy of Sciences. Published by Elsevier B.V. All rights reserved.

\section{Introduction}

The methanol-to-olefin (MTO) process, combined with the transformation of coal or natural gas to methanol, has been demonstrated to be a successful non-petrochemical route to produce ethylene and propylene [1]. Understanding the mechanism of the MTO reaction has drawn considerable interest over the past several decades because of its ability to produce $\mathrm{C}-\mathrm{C}$ bonds from $\mathrm{C} 1$ reactants.

Previous studies have suggested that the MTO reaction occurs through a hydrocarbon pool (HCP) mechanism [2-8]. The reaction takes place over three periods: the induction period, the steady-state reaction period, and the deactivation period $[9,10]$. During the induction period, small amounts of polymethylbenzenes (PMBs) and their protonated analogues are formed and accumulated within the cages or channel intersections of the molecular sieves that act as the initial reaction intermediates [8,11-14]. After the induction period, methanol conversion is observed and increases autocatalytically. Eventually methanol conversion increases dramatically and polycyclic aromatic molecules and large coke fragments form at the same time, which leads to deactivation of the catalyst [8,15-17]. The time required for the formation of PMBs determines the induction period of the MTO reaction. In the case of ZSM-5 catalyst, we previously investigated reaction behavior and kinetics during the methanol conversion induction period [18]. Our results found that the induction period could be further broken down into three stages: an initial $\mathrm{C}-\mathrm{C}$ bond formation stage, a HCP species formation stage and an autocatalysis reaction stage. A critical value of HCP species, $[\mathrm{HCP}]_{c}$, that is required for starting the autocatalysis reaction (the third stage) was proposed and measured.

SAPO-34 (CHA type, containing chabazite cages and 8-member ring windows) offers excellent MTO activity and selectivity [19], and has been used for industrial applications with a fluidized-bed reactor and regenerator because of the

\footnotetext{
* Corresponding author. Tel/Fax: +86-411-84379998; E-mail: liuzm@dicp.ac.cn

DOI: 10.1016/S1872-2067(15)61110-X | http://www.sciencedirect.com/science/journal/18722067 | Chin. J. Catal., Vol. 37, No. 9, September 2016
} 
rapid deactivation of the catalyst [20]. The aromatic-based cycle is the main reaction mechanism over the cage-type SAPO-34 catalyst. The catalytic performance of SAPO-34 is very different from that of ZSM-5. With larger channel sizes (10-member ring channels), the ZSM-5 catalyst shows less ethylene selectivity but better performance in methanol-to-gasoline, methanol-toaromatics and methanol-to-propylene reactions than SAPO-34 [21-24]. It has been reported that with ZSM-5 catalyst, methanol conversion can proceed according to both the aromatic and the olefin-based cycles during the steady-state stage [25-28]. Based on the different zeolite framework structures, diffusivities, coking behavior and HCP mechanisms between SAPO-34 and ZSM-5 catalysts, it is important to compare the induction stage between SAPO-34 and ZSM-5. This study presents a kinetic investigation of the induction reaction at different temperatures. It is expected to gain more insight into the HCP mechanism.

\section{Experimental}

\subsection{Materials}

SAPO-34 $((\mathrm{Al}+\mathrm{P}) / \mathrm{Si}=16)$ was synthesized as described elsewhere [10]. The SAPO-34-based catalyst for fluidized reaction was prepared using the spray-drying method with an inert binder. Methanol (AR) was purchased from Xinxi Chemical Reagent Company of Shenyang, China.

\subsection{Methanol conversion reaction}

Methanol conversion was carried out in a fluidized-bed reactor, which guaranteed spatial uniformity of the catalytic reaction and coke deposition. Prior to the start of the experiment, $10 \mathrm{~g}$ of freshly calcinated catalyst was loaded into the reactor and pretreated at $550{ }^{\circ} \mathrm{C}$ under He flow (30 mL/min) for 40 min. The temperature was then adjusted to the desired value. By switching a four-port valve, the reactant $(40 \%$ aqueous methanol solution), which was vaporized by a preheater, entered the reactor bottom through a distributor and contacted the catalyst. The space velocity (WHSV) of methanol was 1.5 $\mathrm{h}^{-1}$. The product was detected using on-line gas chromatography (GC) (Agilent 7890A GC, USA) employing a CPPORAPLOT Q-HT $(25 \mathrm{~m} \times 0.32 \mathrm{~mm})$ column and flame ionization detector.

\section{Results and discussion}

\subsection{Methanol conversion reaction at different temperatures}

Changes in methanol conversion with reaction time at different temperatures over SAPO-34 are presented in Fig. 1. At $290{ }^{\circ} \mathrm{C}$, initial methanol conversion was low and almost no methanol conversion was observed, indicating that the initial HCP species were difficult to generate at a low reaction temperature. Methanol conversion ( $>1 \%$ ) was only observed after $100 \mathrm{~min}$, after which the conversion increased more significantly. The highest methanol conversion (11.4\%) occurred after $222 \mathrm{~min}$ and then decreased with gradual deactivation of
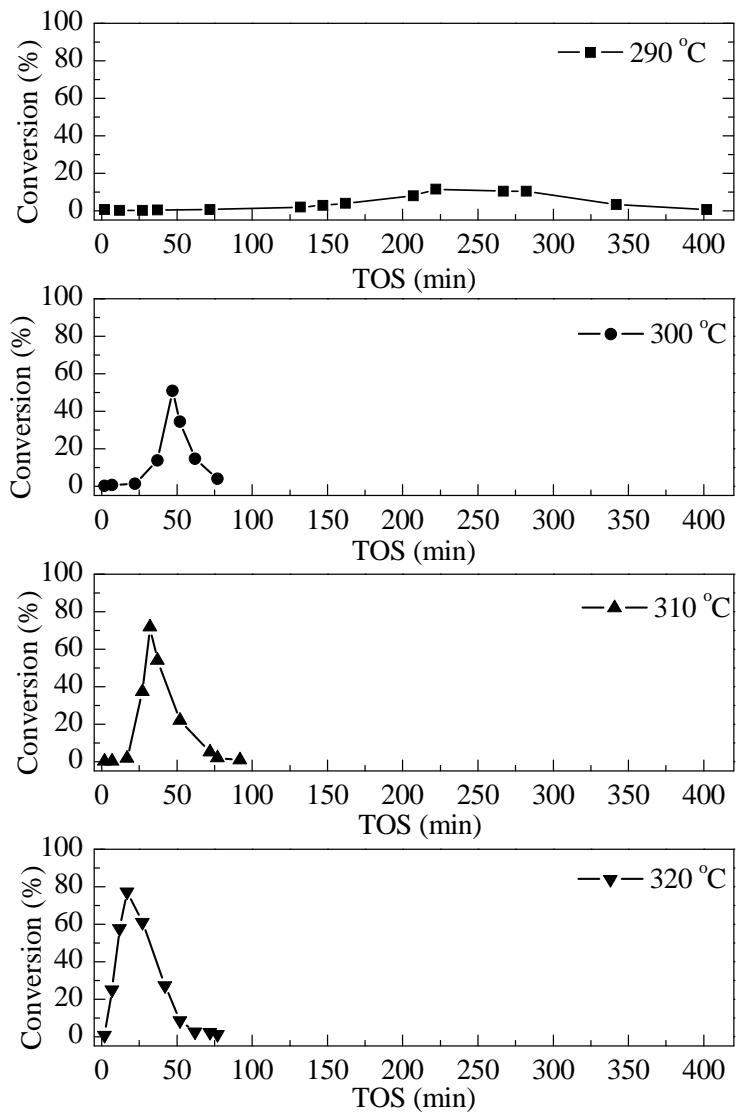

Fig. 1. Methanol conversion changes with reaction time at different temperatures over SAPO-34. TOS: time on stream.

the catalyst. At the higher temperature of $300{ }^{\circ} \mathrm{C}$, the induction period was greatly shortened and the maximum methanol conversion increased to $>50 \%$. The methanol conversion increased more rapidly during the autocatalytic reaction and was followed by faster deactivation compared with the reaction at $290{ }^{\circ} \mathrm{C}$. Clearly, the MTO induction reaction is sensitive to the reaction temperature over the SAPO-34 catalyst. At higher reaction temperatures $\left(310\right.$ and $\left.320^{\circ} \mathrm{C}\right)$, the induction period was further shortened and the maximum methanol conversion continuously increased, followed by more rapid catalyst deactivation. These phenomena are consistent with our previous studies on H-ZSM-5 in a fixed-bed reactor [18].

\subsection{Observation of three reaction stages}

The MTO reaction is a typical autocatalytic process. The initially accumulated HCP species will promote and accelerate the generation of more HCP compounds. To gain deeper insight into how the fresh catalyst is transformed to the active one, detailed reaction stages that evolve during the induction period should be clearly differentiated. In our previous work, three reaction stages were observed over the MTO; induction period and the generation of initial HCP species were shown to occur during the second stage [18]. By plotting the methanol conversion on a logarithmic scale, as illustrated in Fig. 2, three reaction stages can also be distinguished during the induction period at $290{ }^{\circ} \mathrm{C}$ over SAPO-34. According to our previous results 


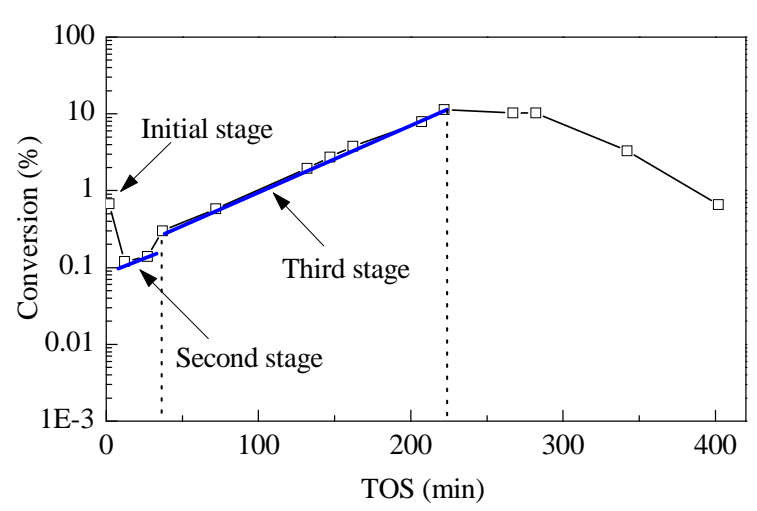

Fig. 2. The three stages of the induction period at $290^{\circ} \mathrm{C}$.

[18], and the changes in methanol conversion during different stages, the three stages can also be described as the initial C-C bond formation stage (the initial stage), the HCP species formation stage (the second stage) and the autocatalysis reaction stage (the third stage) [19]. This indicates that there are similar kinetic characteristics during the induction period over HZSM-5 and SAPO-34, regardless of whether the reaction takes place in a fixed- or fluidized-bed.

\subsection{Calculation of apparent activation energy}

Identification of the three reaction stages during the induction period is helpful for further proving the importance of the HCP mechanism using the SAPO-34 catalyst. However, because of the complexity of the composition of HCP species and HCP mechanism, it is still very difficult to clarify the relationships among the three stages and the evolution of the reaction mechanism in the absence of kinetic investigations. As such, the apparent activation energies of the three reaction stages were calculated following similar methods to our previous work [18].

\subsubsection{The initial stage}

It has been reported that the first $\mathrm{C}-\mathrm{C}$ bond and the initial HCP species (very trace amounts) are generated during the initial stage of the MTO induction period [29,30]. The formation of the first $\mathrm{C}-\mathrm{C}$ bond is very likely to be influenced and disturbed by many factors, such as impurities in the feed and catalyst, reaction temperature and the reactor. Consequently, the initial stage is very sensitive to uncontrollable uncertainties that may make calculated results unreliable. Careful investigation of this stage is required. In this study, the use of a fluidized-bed reactor allowed for more catalyst loading ( $10 \mathrm{~g}$ ) with a uniform temperature distribution inside the catalyst bed, which decreased uncertainties in the kinetic studies. However, despite the relatively simple reaction processes during this stage, it was still very difficult to observe the initial methanol conversion accurately. As a result, calculation of the apparent activation energy for the initial stage was not performed.

\subsubsection{The second stage}

Despite the uncertainty of the initial reaction stage, the existence of the second stage was evident under the conditions
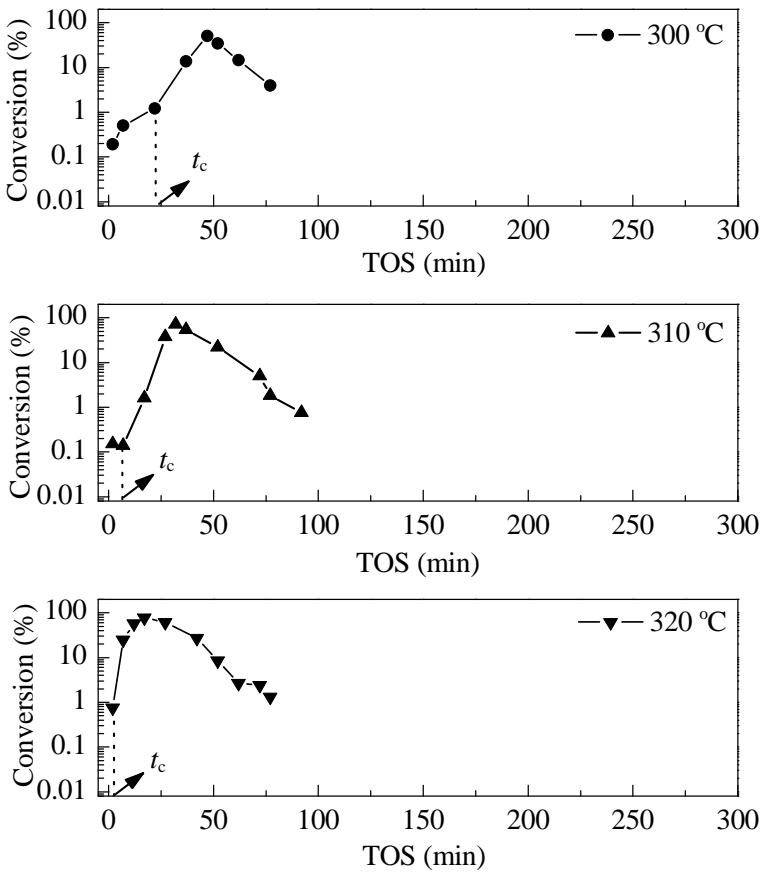

Fig. 3. The time of the second stage during MTO from $300-320{ }^{\circ} \mathrm{C}$ over SAPO-34.

used. During the second stage, certain quantities of HCP species are accumulated to trigger the autocatalytic reaction. It has been shown that the generation and accumulation of HCP compounds are influenced by factors like catalyst topology, acidic site density and contact time [31-34]. Because of the different catalyst topologies and acidities of SAPO-34 and ZSM-5, it was essential to clarify which initial active centers are easily generated for each catalyst. Although the detailed reaction mechanisms for the formation of the organic compounds are complex and it is almost impossible to determine the intrinsic activation energy of the whole process, the value of the calculated apparent activation energy is highly representative and can be used for comparisons.

Using a similar principle as described elsewhere [18], the relationship between the reaction rate constant, $k_{2}$, and the time of the second stage, $t_{c}$, is

$$
k_{2}=1 / t_{\mathrm{c}}
$$

The value of $t_{c}$ in the temperature range $300-320{ }^{\circ} \mathrm{C}$ is shown in Fig. 3 and Table 1.

Fig. 4 presents $\ln k 2$ as a function of $1 / T$ and is a straight line. The activation energy of the second stage of the MTO reaction was $274 \mathrm{~kJ} / \mathrm{mol}$. The acidity of HZSM-5 is much stronger than that of SAPO-34 and coke species are formed much more read-

Table 1

Kinetic parameters and activation energies during the three stages.

\begin{tabular}{lrrrrrr}
\hline \multirow{2}{*}{$T /{ }^{\circ} \mathrm{C}$} & \multicolumn{3}{c}{ Second stage } & & \multicolumn{2}{c}{ Third stage } \\
\cline { 2 - 4 } \cline { 6 - 7 } & $t_{\mathrm{c}} / \mathrm{min}$ & $k_{2} / \mathrm{s}^{-1}$ & $E_{\mathrm{a}} /(\mathrm{kJ} / \mathrm{mol})$ & & $k_{3} / \mathrm{s}^{-1}$ & $E_{\mathrm{a}} /(\mathrm{kJ} / \mathrm{mol})$ \\
\hline 290 & 37 & 0.00045 & 274 & & 0.019 & 332 \\
300 & 22 & 0.00076 & & & 0.12 & \\
310 & 7 & 0.0024 & & & 0.32 & \\
320 & 2 & 0.0083 & & & 0.73 & \\
\hline
\end{tabular}




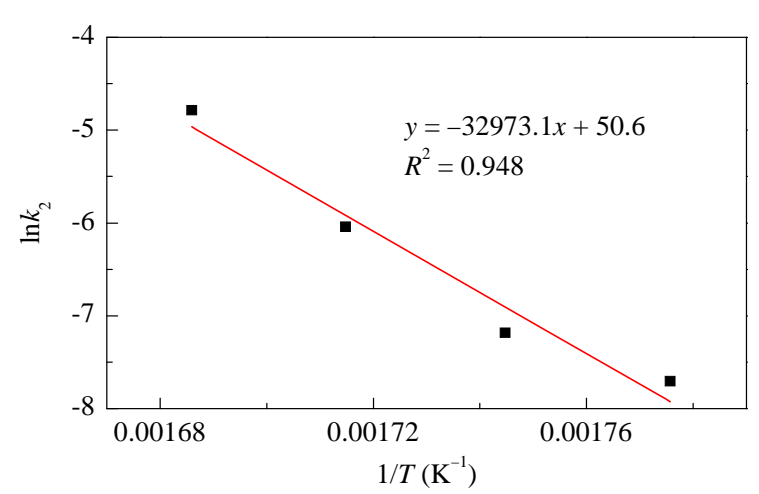

Fig. 4. Arrhenius plot of the rate constant for the second-stage reaction during the MTO induction period at $290-320{ }^{\circ} \mathrm{C}$.

ily over stronger acidic sites. The calculated value in this study was lower than that of HZSM-5 $\left(\mathrm{Si} / \mathrm{Al}=19, E_{\mathrm{a}}=301 \mathrm{~kJ} / \mathrm{mol}\right)$. Considering the factors influencing the second stage, the differences in activation energies could be caused by different topologies and diffusivities of the catalysts. HZSM-5 features an MFI topology made up of a 3D network consisting of sinusoidal $\left(5.1 \times 5.5 \AA^{2}\right)$ and straight $\left(5.3 \times 5.6 \AA^{2}\right)$ channels defined by 10 -rings that results in medium-sized pores. SAPO-34 is a small-pore molecular sieve, featuring a CHA topology with spacious cavities $\left(10 \times 6.7 \AA^{2}\right)$ that are connected by small $(3.8 \times 3.8$ $\AA^{2}$ ) 8-ring windows. HZSM-5 has a much longer lifetime than SAPO-34 during the MTO reaction because of its perfect diffusivity. Because of the limited diffusivity of SAPO-34, the initially formed cyclic compounds and higher olefins are more likely confined in the CHA cages. These retained species would contribute to the generation of active centers and the formation rate would be enhanced because of the spatial confinement effect of the CHA cages. As a result, the accumulation of initial HCP species during the second stage is easier and the apparent activation energy is lower for SAPO-34.

\subsubsection{The third stage}

During the third reaction stage, the methanol conversion reaction was initiated and the reaction proceeded in an autocatalytic fashion. To gain more information about the evolution of coke species during this stage, the apparent activation energy was calculated. As shown in Fig. 2, the methanol conversion, if plotted on a logarithmic scale, is a linear function of TOS for the third stage. As such, the autocatalysis reaction rate can be expressed as:

$$
\begin{aligned}
\ln x & =-k_{3} t+B_{0} \\
x & =B e^{-k_{3} t}
\end{aligned}
$$

where $x$ is the methanol conversion and $k_{3}$ is obtained from Fig. 5 (a). Fig. 5 (b) shows $\ln k_{3}$ as a function of $1 / T$. The activation energy of the autocatalysis reaction stage was calculated to be $332 \mathrm{~kJ} / \mathrm{mol}$.

\subsection{Discussion of the second and third reaction stages}

The kinetic parameters and activation energies during the three stages are summarized in Table 1. With these activation energy data, the evolution of the energy barrier during the MTO
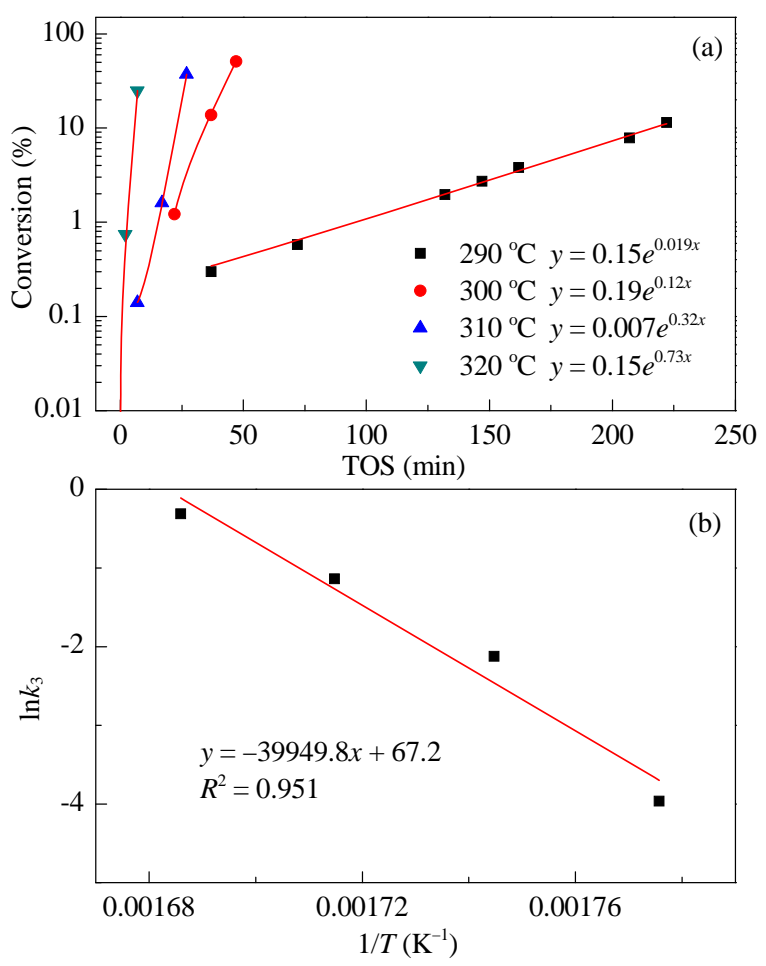

Fig. 5. (a) Conversion of methanol over SAPO-34 zeolite as a function of TOS at different reaction temperatures during the third stage of the MTO reaction; (b) The Arrhenius plot of the rate constant for the autocatalysis stage reaction during the MTO induction period in the temperature range $290-320^{\circ} \mathrm{C}$.

induction period for SAPO-34 could be explained according to Scheme 1.

It is reasonable that after the accumulation of some HCP species the autocatalytic reaction would be initiated and the reaction would proceed more easily during the third reaction stage. However, the apparent activation energy was much higher than that of the second stage. This seemed strange and contradictory to previous research at first glance [18]. But, if we focus on the evolution of coke species during the autocatalytic stage, the result seems reasonable. Much work has previously focused on the evolution of retained species during the autocatalysis stage for ZSM-5 and SAPO-34 [35,36]. For ZSM-5, all of the retained species are active methylbenzenes and their quantities increased continuously as the reaction progressed

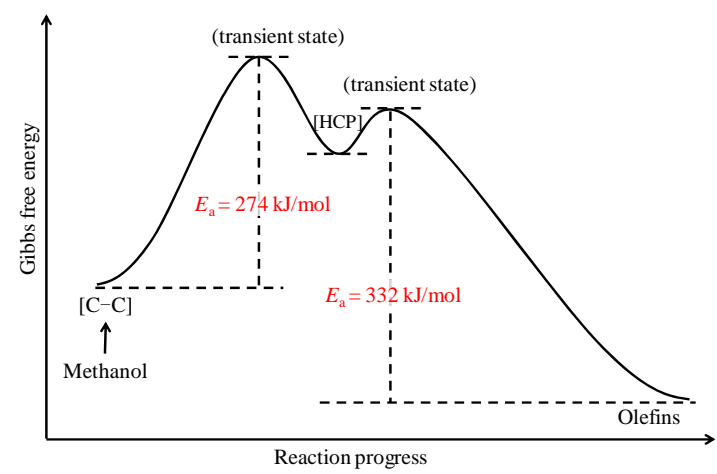

Scheme 1. Evolution of energy barriers during the MTO induction period over SAPO-34. 
during the induction period [36]. For SAPO-34, the coking behavior is different. Besides active species like methylbenzenes and methylnaphthalenes, a large amount of inactive methyladamantanes are also generated and accumulated during the autocatalysis stage [35]. It has been shown that the deactivation of SAPO-34 is caused by the accumulation of methyladamantanes under low reaction temperatures [35]. As a result, the evolution of the HCP mechanism is different over SAPO-34 during the autocatalysis stage of the induction period. The MTO reaction proceeds more readily over HZSM- 5 because more active centers are continuously accumulated. Over SAPO-34, both the active and inactive species are generated and many of them could be retained in the cages because of the limited diffusivity during the induction period. Active species enhance the activity of the catalyst while inactive species inhibit activity. Consequently, the apparent activity of the SAPO-34 catalyst is based on competition between active and inactive species. Also, the proportion of methyladamantanes continuously increased with the progress of the induction reaction and, as a result, the apparent activation energy of the third stage was higher than that of the second stage.

\section{Conclusions}

This study provides new insight into the MTO induction reaction over SAPO-34 catalyst. Three reaction stages were observed that were sensitive to the reaction temperature. Kinetic investigation of the MTO induction reaction was systematically performed and the results were discussed in comparison with those for the ZSM- 5 catalyst. For the first time, we suggest that the limited diffusivity and the spatial confinement effect of the CHA cages could help generate initial HCP species. It is also important to note that the apparent activation barrier increased between the second and third stages because of the continuous formation of inactive methyladamantanes.

\section{References}

[1] M. Stocker, Microporous Mesoporous Mater., 1999, 29, 3-48.

[2] A. Sassi, M. A. Wildman, H. J. Ahn, P. Prasad, J. B. Nicholas, J. F. Haw, J. Phys. Chem. B, 2002, 106, 2294-2303.
[3] B. Arstad, J. B. Nicholas, J. F. Haw, J. Am. Chem. Soc., 2004, 126, 2991-3001.

[4] P. W. Goguen, T. Xu, D. H. Barich, T. W. Skloss, W. G. Song, Z. K. Wang, J. B. Nicholas, J. F. Haw, J. Am. Chem. Soc., 1998, 120, 2650-2651.

[5] W. G. Song, J. B. Nicholas, J. F. Haw, J. Phys. Chem. B, 2001, 105, 4317-4323.

[6] W. G. Song, D. M. Marcus, H. Fu, J. O. Ehresmann, J. F. Haw, J. Am. Chem. Soc., 2002, 124, 3844-3845.

[7] M. Bjorgen, U. Olsbye, D. Petersen, S. Kolboe, J. Catal., 2004, 221, $1-10$.

[8] M. Bjorgen, U. Olsbye, S. Kolboe, J. Catal., 2003, 215, 30-44.

[9] Y. X. Wei, D. Z. Zhang, F. X. Chang, Z. M. Liu, Catal. Commun., 2007, 8, 2248-2252.

[10] P. Tian, Y. X. Wei, M. Ye, Z. M. Liu, ACS Catal., 2015, 5, 1922-1938.

[11] D. Lesthaeghe, V. Van Speybroeck, G. B. Marin, M. Waroquier, Angew. Chem. Int. Ed., 2006, 45, 1714-1719.

[12] W. G. Song, J. F. Haw, J. B. Nicholas, C. S. Heneghan, J. Am. Chem. Soc., 2000, 122, 10726-10727.

[13] J. B. Nicholas, J. F. Haw, J. Am. Chem. Soc., 1998, 120, 11804-11805.

[14] D. M. McCann, D. Lesthaeghe, P. W. Kletnieks, D. R. Guenther, M. J. Hayman, V. Van Speybroeck, M. Waroquier, J. F. Haw, Angew. Chem. Int. Ed., 2008, 47, 5179-5182.

[15] J. F. Haw, W. G. Song, D. M. Marcus, J. B. Nicholas, Acc. Chem. Res., 2003, 36, 317-326.

[16] J. F. Haw, D. M. Marcus, Top. Catal., 2005, 34, 41-48.

[17] F. Bleken, M. Bjorgen, L. Palumbo, S. Bordiga, S. Svelle, K. P. Lillerud, U. Olsbye, Top. Catal, 2009, 52, 218-228.

[18] L. Qi, Y. Wei, L. Xu, Z. Liu, ACS Catal,, 2015, 5, 3973-3982.

[19] J. Liang, H. Y. Li, S. Zhao, W. G. Guo, R. H. Wang, M. L. Ying, Appl. Catal., 1990, 64, 31-40.

[20] G. Ondrey, Chem. Eng., 2011, 118(2), 16-20.

[21] M. Bjorgen, F. Joensen, M. S. Holm, U. Olsbye, K. P. Lillerud, S. Svelle, Appl. Catal. A, 2008, 345, 43-50.

[22] M. Conte, B. Xu, T. E. Davies, J. K. Bartley, A. F. Carley, S. H. Taylor, K. Khalid, G. J. Hutchings, Microporous Mesoporous Mater, 2012, 164, 207-213.

[23] S. Sadeghi, M. Haghighi, P. Estifaee, J. Nat. Gas. Sci. Eng., 2015, 24, 302-310.

[24] J. G. Zhang, W. Z. Qian, C. Y. Kong, F. Wei, ACS Catal., 2015, 5, 2982-2988.

[25] I. M. Dahl, S. Kolboe, J. Catal., 1994, 149, 458-464.

[26] I. M. Dahl, S. Kolboe, J. Catal., 1996, 161, 304-309.

[27] S. Svelle, F. Joensen, J. Nerlov, U. Olsbye, K. P. Lillerud, S. Kolboe, M.

\section{Graphical Abstract}

Chin. J. Catal., 2016, 37: 1496-1501 doi: 10.1016/S1872-2067(15)61110-X

\section{Methanol-to-olefin induction reaction over SAPO-34}

You Zhou, Liang Qi, Yingxu Wei, Cuiyu Yuan, Mozhi Zhang, Zhongmin Liu* Dalian Institute of Chemical Physics, Chinese Academy of Sciences; University of Chinese Academy of Sciences

During the MTO induction reaction over SAPO-34 we found that the whole induction period could be divided into three reaction stages. The induction reaction behavior was different from that over the ZSM-5 catalyst.

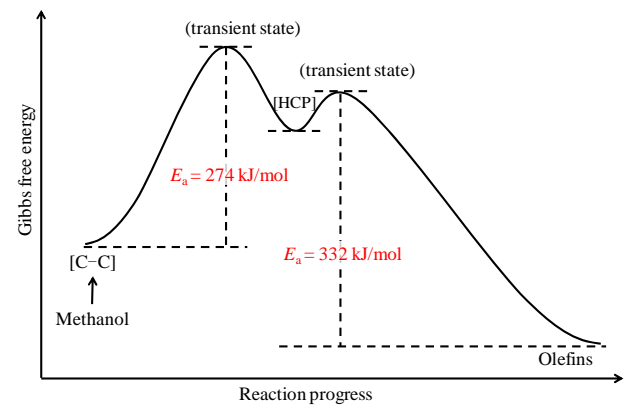


Bjorgen, J. Am. Chem. Soc., 2006, 128, 14770-14771.

[28] M. Bjorgen, S. Svelle, F. Joensen, J. Nerlov, S. Kolboe, F. Bonino, L. Palumbo, S. Bordiga, U. Olsbye, J. Catal., 2007, 249, 195-207.

[29] J. F. Li, Z. H. Wei, Y. Y. Chen, B. Q. Jing, Y. He, M. Dong, H. J. Jiao, X. K. Li, Z. F. Qin, J. G. Wang, W. B. Fan, J. Catal., 2014, 317, 277-283.

[30] W. L. Dai, C. M. Wang, M. Dyballa, G. J. Wu, N. J. Guan, L. D. Li, Z. K. Xie, M. Hunger, ACS Catal., 2015, 5, 317-326.

[31] J. R. Chen, J. Z. Li, Y. X. Wei, C. Y. Yuan, B. Li, S. T. Xu, Y. Zhou, J. B. Wang, M. Z. Zhang, Z. M. Liu, Catal. Commun., 2014, 46, 36-40.

[32] J. R. Chen, J. Z. Li, C. Y. Yuan, S. T. Xu, Y. X. Wei, Q. Y. Wang, Y. Zhou,
J. B. Wang, M. Z. Zhang, Y. L. He, S. L. Xu, Z. M. Liu, Catal. Sci. Technol., 2014, 4, 3268-3277.

[33] Y. X. Wei, D. Z. Zhang, F. X. Chang, Z. M. Liu, Catal. Commun., 2007, 8, 2248-2252.

[34] J. Z. Li, Y. X. Wei, J. R. Chen, S. T. Xu, P. Tian, X. F. Yang, B. Li, J. B. Wang, Z. M. Liu, ACS Catal., 2015, 5, 661-665.

[35] Y. X. Wei, J. Z. Li, C. Y. Yuan, S. T. Xu, Y. Zhou, J. R. Chen, Q. Y. Wang, Q. Zhang, Z. M. Liu, Chem. Commun., 2012, 48, 3082-3084.

[36] L. Qi, J. Z. Li, Y. X. Wei, L. Xu, Z. M. Liu, Catal. Sci. Technol., 2016, 6, 3737-3744.

\title{
SAPO-34 催化剂上甲醇制烯烃诱导期反应
}

\author{
周 游 ${ }^{\mathrm{a}, \mathrm{b}}$, 元 良 ${ }^{\mathrm{a}, \mathrm{b}}$, 魏迎旭 ${ }^{\mathrm{a}}$, 袁翠峪 ${ }^{\mathrm{a}}$, 张默之 ${ }^{\mathrm{a}, \mathrm{b}}$, 刘中民 ${ }^{\mathrm{a},{ }^{*}}$ \\ a 中国科学院大连化学物理研究所, 洁净能源国家实验室(筹), 甲醇制烯烃国家工程实验室, 辽宁大连 116023 \\ 中国科学院大学, 北京 100049
}

摘要: 甲醇制烯烃 (MTO) 是典型的自催化过程, 包含诱导期反应. 在诱导期反应中, 甲醇转化生成的烃池物种在分子篎催 化剂上积累, 形成含有活性中心的烃池, 从而进一步促进和加快更多烃池物种的生成. 作为 MTO 反应的活性中间体, 研究 分子笁上烃池物种及其演变, 对于理解 MTO 反应机理以及 C1 化学中第一个 C-C 键的生成具有重要意义.

本文采用 SAPO-34 分子篎催化剂, 对较低温度下流化床反应器中 MTO 诱导期反应进行研究, 获得了诱导期反应的数 据. 通过 HF 溶解分子耖骨架的方法, 检测各阶段存留在 SAPO-34 分子篎催化剂中的有机物种, 分析了分子篎催化剂上烃 池物种的积累和演变、烃池的形成以及烃池物种与催化剂失活之间的关系, 并结合诱导期反应数据进一步讨论了 MTO 诱 导期反应的动力学.

研究发现, 与 ZSM-5 分子篮类似, SAPO-34 分子笁上的 MTO 诱导期反应对温度非常敏感. 诱导期证实可分为三个反 应阶段: 初始反应阶段 (最初 C-C 键生成阶段)、第二阶段 (烃池物种的生成和积累阶段) 及第三阶段 (自催化反应阶段). 这表明 SAPO-34 分子篮上 MTO 反应中烃池机理的重要性. 然而, 由于烃池物种和烃池机理的复杂性, 在缺乏动力学研究 的情况下, 很难将诱导期反应三个阶段与反应机理进行明确的关联. 因此, 我们分别讨论了诱导期反应三个阶段的动力学, 并计算了各阶段的表观活化能.

动力学研究表明, 与 ZSM-5 不同的是, 在 SAPO-34 上的 MTO 诱导期反应中, 初始反应阶段表观活化能较低, 反应进 行相对容易; 而自催化反应阶段的活化能较高, 反应进行相对困难. 这主要是 SAPO-34 与 ZSM-5 分子篮的结构差异所致. SAPO-34 分子篮因具有 CHA 结构而导致的扩散限制和空间约束, 使得在第一阶段初始活性物种的生成和积累相对容易; 但是在自催化反应阶段, 不具活性的金刚烷类物质开始生成, 并随着反应的进行在所有积碳物种所占的比例逐渐升高, 导 致其在自催化反应阶段 (第三阶段) 的活化能高于烃池物种的生成和积累阶段 (第二阶段). 对于 HZSM-5 催化剂上的 MTO 诱导期反应, 由于 MFI 结构所产生的扩散限制和空间约束低于 CHA 结构, 在第一阶段初始活性物种的积累相对困 难, 导致其初始阶段的表观活化能高于 SAPO-34 催化剂; 但是随着反应的进行, 活性物种在 HZSM-5 催化剂上不断积累, 导致自催化反应阶段的进行相对比较容易. 然而, 对于 SAPO-34 分子笁上 MTO 诱导期反应, 随着反应时间的推移, 催化 剂上积累的活性物种和非活性物种同时增多, 而且由于 SAPO-34 结构特点而引起的扩散限制, 大部分物种均保留在 SAPO-34 分子篮的笼中. 分子篮中活性物种能提高反应活性, 相应地, 非活性物种则会抑制反应活性. 因此, SAPO-34 分 子笁上甲醇转化诱导期反应活化能反映的是活性物种和非活性物种之间的竞争关系.

关键词: 甲醇制烯烃; 活化能; SAPO-34 催化剂; 烃池; 诱导期

收稿日期: 2016-03-26. 接受日期: 2016-04-18. 出版日期: 2016-09-05.

*通讯联系人. 电话/传真: (0411)84379998; 电子信箱: liuzm@dicp.ac.cn

本文的英文电子版由Elsevier出版社在ScienceDirect上出版(http://www.sciencedirect.com/science/journal/18722067). 